\title{
Capital Market and the Development of the Small And Medium - Scale Enterprises in Nigeria.
}

\author{
${ }^{1}$ Modinat O. Olusoji, ${ }^{2}$ Edwin E. Enofe \\ 1. M.O. Olusoji works with Centre for Management Development (CMD), Ibadan Zonal Office, Nigeria \\ 2. E.E. Enofe also works with the same CMD
}

\begin{abstract}
This paper looked at the need to incorporate the Small and Medium Scale enterprises (SMEs) into the capital market in Nigeria as a means of raising capital for their operations. The findings of the paper found that the growth in the transactions of the quoted companies has been fluctuating over the years. The paper concludes that relaxation of conditions for listing of the SMEs in the stock exchange market and provision of enabling environment for SMEs to thrive in Nigeria will enhance the growth in the transactions of the capital market.

Keywords: Capital Market, Development, SMEs, Nigeria
\end{abstract}

\section{Introduction}

The rapid development of small and medium-scale enterprises (SMEs) is one of the instruments of tackling poverty in an economy. Both in literature and practice, poverty alleviation has always formed the nucleus of economic development policies in many developing countries- including Nigeria (Lemo, 2002). Most of the poor are found in one SMEs activities or the other, hence the policies focused on the development of these SMEs will not only aid in reducing poverty but will also promote economic growth and development of the economy. This is because economic growth and development is sustainable only if it is accompanied by the economic empowerment and mass participation of the citizens in the economic and social life of a nation. SMEs perform such functions as employment generation, acceleration of rural development, utilization of domestic resources, formation of competitive environment and maintenance of innovative activity. From this type of business, maximum results of economic development can be achieved, and it also has a sensation of a market (Toktarova, 2004).

The recognition of the role of SMEs, has made successive governments to be interested in SMEs, and caused them to implement various measures and programmes in Nigeria in order to encourage their development. Despite these measures, SMEs are still plagued with myriads of problems, among which is finance. Finance is a major problem that has inhibited the growth of SMEs. Some of the constraints of inadequate SME financing include inadequate collateral to secure loans from private credit institutions, poor feasibility studies and lack of equity contribution, among others. Although, the second tier security market was introduced in 1985 to cater for small indigenous companies to be quoted in the stock exchange, yet only few were listed because of requirements and as well as the fact that some of these entrepreneurs do not want to share their companies with the public. Based on the foregoing, this paper discusses the possibilities of developing the SMEs through the capital market option. The rest of paper is divided into four sections. Following this introduction is the conceptual and theoretical framework in Section 2. Section 3 contains the literature review while Section 4 presents the challenges and prospects of developing the SMEs in Nigeria through capital market. Section 5 concludes the paper.

\section{1: $\quad$ Conceptual Clarifications}

\section{Conceptual/Theoretical Framework}

The key concepts - capital market, development, and small and medium-scale enterprises in this paper will be clarified below with the aim of showing their interrelationships in the subject matter.

\subsection{1: Capital Market}

Capital market is the financial market segment that is established for the mobilization and utilization of long-term funds for social, economic and industrial development. The instruments traded in the market include government bonds, company shares and mortgage loans (Anyanwu et al, 1997: Anyanwu, Oyefusi, Oaikhenan and Dimowo, 1997; Ayodele and Falokun, 2003). United Nations Institute for Training and Research (UNITAR), 2004, put it that the capital market refers to the buying and selling of capital investments, usually equity or debt investments to be used by a business in its growth and development.

There are two segments of the capital market in general: primary and secondary markets. Primary market refers to the offering of securities by the company to the public. It can be an "initial public offering (IPO)", and for an offering of additional securities by a company that already has its securities listed in the market. In either case, 
the primary market refers to the first issuance of securities to the buyers from the company. The company issuing the securities is called the "issuer", and their (securities) sales are made directly by the issuer or through "underwriters;" while the buyers are called the investors, who put in their money in purchasing the financial instrument of the issuer for the purpose of earning dividend. Secondary market segment is where existing security holders, such as shareholders, offer their shares for sale in the stock exchange or over-the-counter market. In the other words, the secondary market is the buying and selling of securities among shareholders. While the stock exchange is the floor for buying and selling of shareholders' stocks, the over-the-counter market is the secondary market for trading securities that are not listed on an exchange; and it is operated by broker-dealers who provide stock quotations and match buy and sell orders (UNITAR, 2004). In Nigeria, participants in the market include the Nigerian Stock Exchange, Discount Houses, Development Banks, Investment Banks, Building Societies, Stock-broking Firms, Insurance and Pension Organisations, Quoted Companies, the Government, Individuals, and the Nigerian Securities and Exchange Commission (Anyanwu, et al, 1997).

\subsection{2: Development}

By development in this context, we mean the small and medium-scale enterprises development. Development here refers to the gradual growth which is an increase in size of the small and medium scale enterprises so that they become more advanced and financially stronger to cope with business challenges, continuity and meeting with the goal of profit making and realizing dividends to the shareholders (Hornby, 2000). Growth here also involves an increase in the size, opportunities, and number of shareholders, businesses and business links, et cetera. of the small and medium-scale enterprises.

\subsection{3: $\quad$ Small and Medium-Scale Enterprises (SMEs)}

The definition of SMEs varies from country to country. For example, while UNITAR (2004) defines small and medium-scale enterprises (SMEs) as privately owned businesses that are too small or relatively small to engage in large-scale public offerings of securities, Central Bank of Nigeria (CBN, 1997), noted the definition of SMEs by the National Council of Industries in Nigeria as those with total investment of above N40 million but not exceeding $\$ 150$ million and labour size of between 35 and 100 workers. In general, the clarification of SMEs varies by assets, number of employees or annual sales.

The International Finance Corporation (IFC), in Hamid (2004), defines SMEs as firms with less than 300 employees and total assets less than US One million. From this IFC's definition, it can be seen that the majority of businesses in Nigeria are SMEs. In Nigeria, a market, called the Second-tier Securities Market (SSM), was established for the SME on $30^{\text {th }}$ April, 1985. The SSM is meant to assist small and medium-sized companies that are unable to meet the requirements of the first-tier market (NSE) in raising long-term capital. To encourage the development of the SSM, the stringent conditions for enlisting in the first-tier market were relaxed for indigenous enterprises seeking to raise funds through the SSM (Anyanwu et al, 1997).

The simplified listing requirements, which constituted the basic distinguishing features of the

SSM, were that prospective companies should:

(i) have a 3-year trading record instead of the 5-year required for full listing at the NSE;

(ii) submit audited half-year and annual statements without the quarterly statement required for listing in the first-tier market;

(iii) make at least $10 \%$ of their equity capital available for public subscription, and against the $25 \%$ minimum required for full listing;

(iv) have not less than 100 shareholders, compared with the 500 prescribed minimum for full listing in the NSE;

(v) make flat annual subscription of $\$ 2,000$ to the stock exchange instead of the graduated annual quotation fees based on the companies' share capital in the NSE;

(vi) raise a maximum of $\$ 5$ million in the market whereas there is no limit to the amount that could be raised in the NSE; and

(vii) an individual can own not more than $75 \%$ share under the SSM requirements.

Given the above conceptual clarifications on capital market, development of the SMEs, and the SMEs, it is evident that the SMEs fall under the second-tier securities market (SSM), but investors usually see the SSM as inferior to the NSE stock. Hence, trading in SSM stocks tends to be sparse. This adversely affects both stock prices and liquidity. The potential of a Tier II listing is thus a meager inducement for SME's and potential investors (Odife, 2002). It, therefore, follows that the Nigerian Capital Market can develop the SMEs, through a more appropriate policy framework in order to assist in the overall development of the Nigerian economy.

\subsection{Theoretical Framework}

The theoretical basis for research on the SMEs finance originates from the corporate finance theory. The pecking order theory (POT) of financing hypothesises the issue of information asymmetries whereby only 
the firm manager is aware of the true value of the firm and the fact that the market is unaware of the true distribution of the firm's income. Because investors assume that managers will only issue stock when they believe it to be overvalued, this implies that a new issue of stock will be taken as a 'bad signal' by the markets, thus triggering a reduction in the share price. Myers (1984) extends this theory and states that firms will meet investment and financing requirements of the firm in a hierarchical fashion, preferring internal funds first, external debt next and external equity as a last resort.Literature provides a number of demand-side and supplyside reasons as to why firms prefer (a) internal sources of funding over external sources, and (b) debt over equity. Stiglitz and Weiss, (1981) argues that supply-side constraints exist when SMEs cannot obtain the debt financing they require at market interest rates, resulting in undercapitalisation. This is viewed as an underinvestment problem, where equity clears the market.

Demand-side explanations as presented by Bolton (1971) and LeCornu et al.(1996) are based on the well-established fact that SME owners are extremely reluctant to relinquish control of their business (e.g.). SME owners will try to meet their financing needs from a pecking order of, first, their "own" money (personal savings and retained earnings); second, short-term borrowings; third, longer term debt; and, least preferred of all (Ciarán mac an \& Lucey 2006). Studies on small business finance have frequently suggested the problem of scarcity of funds (Peel and Wilson, 1996; Laitinen, 1992). It is also observed that limited debt funding opportunities (Holmes et al., 1994) and limited access to capital markets (Gopinath, 1995) appear to confine the finance of small businesses to internally generated funds. However, there is a limit to which internally generated fund can contribute to the growth of the SMEs which bring to the fore the need for alternative source of capital for development of these enterprises.

\section{Literature Review}

It has been estimated that SMEs accounted for about 70 percent of total industrial employment in the country (Olusoji, 1999); therefore, whatever the definition of SMEs, and/or the size of the economy, the growth of SMEs is very crucial to the growth of that economy. Audretsch (2000) concluded, from his study on the analysis of SMEs role in United States, that they contribute the greatest amount of net employment to the economy. Weller (2004), argues that development of SMEs can reduce poverty and regional disparities as SMEs provide job access to less qualified and/or young people. Luetkenhorst (2004) also argues that SMEs are important in applying new technologies to better satisfy consumer needs, and contribute most innovations in immature, relatively un-concentrated economies. He argues further that SMEs help to build up an industrial system that is interlinked with significant positive externalities to surrounding economy, which is critical in attracting foreign direct investment.

It has been established in the literatures that small businesses are faced with the problem of scarcity of funds (Peel and Wilson, 1996; Laitinen, 1992). Holmes et al., (1994), observed that they have limited debt funding opportunities and Gopinath (1995) raises the issue of limited access to capital markets as a major constraint. All these appear to confine the finance of small businesses to internally generated funds. Kimki (1997) argues that entrepreneurs to rely on personal savings, friends, and relatives as primary sources of capital at the start-up stage because of the limited ability of SMEs to acquire debt during the early stages.

According to International Labour Organization (ILO)(2000), SMEs are necessary engines for achieving national development goals such as economic growth, poverty alleviation, democratization and economic participation, employment creation, strengthening the industrial base and local production structure. However, the ability of SMEs to realize these economic and social objectives depend on the regulatory and policy environment within which they operate. Capital Market plays a crucial role in mobilizing domestic resources and in channelling these efficiently to the most productive investment. The capital market is thus an important determinant of a country's level of savings, efficiency in investment and, ultimately its rate of economic growth (Hamid, 2004).

In Nigeria, although several Nigerian Securities were actually listed in London before independence, the local listing for dealing with stocks and shares was only considered worthwhile at the registration (establishment), incorporation and operations of the Lagos Stock Exchange in 1959, 1960 and 1961 respectively (Anyanwu, et al). The Nigerian Stock Exchange (NSE) is the centre point of the Nigerian Capital Market, while the Securities and Exchange Commission (SEC) serves as the apex regulatory body. The NSE provides a mechanism for mobilizing private and public savings, and makes such funds available for productive purposes (Nigeria Business Info.com, 2004). The major instrument used to raise fund at the Nigeria Capital Market are Equities (ordinary shares and preference shares). Other instruments in the market include debt (Government bonds), industrial loans/Debenture Stocks and Corporate Bonds. Oyejide (1993) noted that there is apparently a large and influential body of opinion, which regards access to credit as a major determinant of the development of small-scale and micro enterprises (SSMEs) in the developing world.

Nigerian Institute of Social and Economic Research - NISER (1987) noted that as much as 70 per cent of SSMEs obtain most of their investment funds from personal savings. This lack of access to formal credit from formal financial institutions is thought to drive SMEs to high interest charging moneylenders, and hinders their growth 
and development. Oyejide (1993) argues that the problem of high interest rates has often been used as the justification for establishing special financial agencies and programmes to provide credit for SSMEs.

However, the banks are reluctant to lend money to them because they believed that lending to them is not commercially viable (Odife, 2002). It was even alleged that $\$ 11$ billion accumulated by the Nigerian banks as SMEs reserves were not given to them. The Bank also regarded lending to SMEs as a high risk and unprofitable business due to unavailability of accurate and reliable information on the financial condition and performance of the enterprises; unconvinced and weak business plan; weakness in management and information technology. Other problems include banks' weaknesses in identifying characteristics of SMEs; availability of other profitable investment to banks; higher overhead cost to the bank due to a high number of customers with smaller loan size; and higher interest rate on the loans from the informal lending market (Rudjito, 2003). This low financial opportunities of the SSMEs from official financial institutions calls for the need for involvement of the capital market in developing SMEs in Nigeria

\section{Challenges And Prospects Of The Development Of The Smes In Nigeria Through The Nigerian Capital Market}

There are challenges for financing SMEs through the capital market. These challenges, as discussed by Cohn (2003); include company laws limitations; listing on Stock Exchanges; tax and financial disclosure and control concerns. The process of registration is the same for both small and large company. This process is very costly and time consuming and there had not been any exception to the registration process. This poses a challenge to the SMEs in financing their business through the capital market.

The listing requirements of the various countries stock exchanges are normally high in terms of company assets, number of shareholders and market capitalization. The cost of listing to raise a small amount of funds had proved to be as costly as raising large amount of funds.

The prospectus and investment statement normally demand so much detailed information, which are too cumbersome for SMEs to satisfy. The existence of second tier market was in a bid to address these problems. However, many investors regard the second tier companies as those that are not good enough; and as such, limit the trading on the market. In addition, despite the fact that the listing requirement for SSM in Nigeria and UK is quite similar, yet the SSM in UK is performing better than that of Nigeria. Available data showed that UK SSM grew by 37.5 per cent within 3 years while that of Nigeria fell by 16.3 per cent within three years (Nigerian capital market data bank, 2006). In addition, the number of listing in the SSM in Nigeria remains static since 1998. Table 1 attest to this. A study of SSM that was carried out in 2005 showed that there was an initial enthusiasm at the inception of the market resulting in slow but steady growth. However the SSM sector has been declining over time and had become stagnant in terms of listed companies. Thus, the number of listed companies peaked in 1993 with when there were twenty-three (23) companies listed on the SSM. It however dropped to nineteen (19) in 1997 and further to sixteen (16) in 1998 where it remained to date. It was reported that there had been no new listings on the SSM for over a decade (The Nigerian Capital Market Data Bank, 2006) Cohn (2003) argued that the inability of SMEs to meet the exchange listing requirements would not have been a serious hindrance to public offering if there were over- the counter (OTC) market for secondary trading. This is because an OTC market will perform a liquidity function similar to that of exchange for the shareholders. However, this market has not been functioning effectively in Nigeria, as it ought to. The OTC market is only functioning in the trading of bonds. The tax and financial disclosure poses another challenge for SMEs as most companies keep two types of records, one for tax purposes and owner set of record, which discloses the true record. Another challenge has to do with the reluctance of the owner to go public to avoid losing management control.

It needs be noted, however, that the small and medium-scale enterprises have a lot of prospects if the following can be put in place: tax incentives; education of SMEs' Managers; and small business loan programme, among others. With respect to the OTC, the brokerage firm should be further encouraged to freely educate the public and trade in the markets for SMEs and other unlisted companies. This will encourage SMEs to consider raising capital through public or limited offering; and as such, potential investors will be guaranteed of the secondary market for resale of their securities.

In addition, the issue of control could be taken care of by educating the owners of SMEs that they can still maintain control of the company. Added to this is that awareness should be created on the other significant economic benefits that can result from a public market in a company's securities. It is also necessary that programmes should be developed to assist SMEs in obtaining capital. The implementation of the $10 \%$ set aside for investment in the equity of SMEs and Small Scale Industries (SSI) in Nigeria is necessary. This is because it is alleged that the bulk of funds other than this $10 \%$ is invested in the larger businesses (Odife, 2002). From Table 2, All-Share Index, which was only 233.6 in 1988 rose to $24,085.76$, about $10,210 \%$ growth in 2005 . This growth over the 18- year period under consideration is very tremendous, but without the values of the SMEs' transactions being included. This impressive performance could be attributed to several factors including improved market performance, privatisation and commercialisation policy, and infrastructural development as a 
result of the introduction of the automated trading system (SEC, 2001). The influence of the policy on privatisation and commercialisation of public enterprises on the tremendous growth of the share - index cannot be overemphasized. The Federal Government of Nigeria, on $27^{\text {th }}$ July, 1988, promulgated the privatisation and commercialisation programme, under Decree No. 25 of 1988. The Decree provided for the establishment of Technical Committee on Privatisation and Commercialisation (TCPC). The implementation of indigenization programme and privatization policy has led to the expansion of the Nigerian Stock Exchange (NSE) Market in its scope and operations.

Moreover, since the implementation of privatization policy, there has been the formation of Zonal Shareholders' Association, which has revolutionised the corporate ownership structure of enterprises in Nigeria in the sense that just one or few individuals no longer own these enterprises but many shareholders do. Besides, it has created a sense of awareness of the merits of share ownership as a form of savings. This policy and its concomitant awareness creation have expanded the frontiers of the Nigerian Capital Market. For example, of the 142 companies listed in 1991 on the NSE, 25 of them came in through privatisation policy.

The number of listed companies, which was 102 in 1988, 181 in 1995, stood at 302 in 2006. The trading volume in Nigeria, which was 3.95 billion shares in 1999 stood at 26.7 billion shares in 2005. The market capitalisation, which was only N10 billion in 1988, had grown to the tune of N5.12 trillion in 2006. This arose from the stimulation to borrow from the capital market and also from increase in the floating of shares. This is evidence that the market is gaining prominence in the country. The Stock Exchange started with call-over trading system but presently uses an Automated-trading system. With the growing use of internet, telephone and computer network for secondary securities trading, effective functioning of OTC market will go a long way to encourage the development of the SMEs in Nigeria.

From Table 3, the number of deals of stocks and their monetary equivalents reveal that there is largely unstable growth, seeing that there are both positive and negative growths from time to time. The positive growth may have been attributable to the awareness that has been created to the public about the relevance of the capital market, which has encouraged a number of investors to buy shares, culminating in increase in the number of deals on shares in the Exchange (NSE).

The negative growth may have come about as a result of fears of investors loosing their investment due to their inability to receive dividends or receiving low amount of dividends over time, hence selling off or redeeming their investments. This lack of receipts of dividends by shareholders was seen in some privatised institutions, like a number of banks, which became distressed along the line due to mismanagement of shareholder's funds. We expect that the SMEs's values would bring about improvement on the growth of the market if the secondary market has developed to the extent of incorporating them extensively into the capital market. However, the global economic meltdown and financial crisis arising from the international capital market that took place from 2008 had not allowed these Nigerian SMEs to develop meaningfully. This situation has been observed by different authors. For example, Wikipedia, the Free Encyclopedia (2012) noted that the global financial crisis that began in 2008 caused a severe crisis among Nigerian banks, with several forced to close; and that after the Central Bank had audited the banks in 2009, the SEC started legal proceedings at the Investments and Securities Tribunal against about 260 individuals and entities, alleging that they were involved in abuses such as insider dealing and share price manipulation. The commission also instituted various reforms including improving regulations so as to encourage development of the bond market, promoting collective investment schemes and reviewing the 2003 Corporate Governance Code. The unstable and inconsistent values in the capital market data also justify the negative effects of the global financial crisis.

\section{Conclusion/Recommendations}

This paper looked at the need to incorporate the SMEs into the capital market in Nigeria as a means of raising capital for their operations. The finding of the paper is that the growth in the transactions of the quoted companies in the capital market has been fluctuating over the years. The conclusion of the paper is that the incorporation of the SMEs into the stock exchange transactions in Nigeria will enhance the growth in the transactions of the capital market in Nigeria.

To make this a reality, this paper recommends the following in line with other authors' opinion on the subject matter.

1. There should be further development of the use of the internet, telephone and computer networking to accelerate effective functioning of the over-the counter market, so that all stocks can be traded in the secondary market.

2. Modifying the registration requirements of the SMEs in the capital market. Some registration conditions that hinder the SMEs to operate in the capital market should be relaxed to enable them to operate.

3. Tax incentives should be given to the SMEs in order for them to have the funds they would have committed into tax for their operations. This will go a long way to revive SSM and enable those that have not been listed to be listed in the capital market. 
4. Effort should be made to help indigenous companies that are quoted in the capital market to attract quality investment by taking advantage of the opportunities that is being promoted by public and private sectors collaboration.

5. There is need for educating the SMEs operators on the necessity of being listed in the stock exchange.

6. Government should provide enabling environment for SMEs to thrive and to stimulate the interest of local investors in investing on the enterprises. This can be done by providing adequate infrastructure to reduce the cost of doing business in the country; and also taking measures to ameliorating the negative impact of the global economic meltdown and financial crisis on the SMEs in Nigeria.

Given these recommendations, among others, with their effective implementation, it is hoped that the SMEs in Nigeria will grow and subsequently contribute to the overall growth of the Nigerian economy, and also alleviate poverty in the economy.

TABLE 1: Number of SSM in Nigeria

\begin{tabular}{|c|c|}
\hline Year & No of SSM During the period \\
\hline 1985 & 1 \\
\hline 1986 & 3 \\
\hline 1987 & 4 \\
\hline 1988 & 6 \\
\hline 1989 & 9 \\
\hline 1990 & 16 \\
\hline 1991 & 19 \\
\hline 1992 & 21 \\
\hline 1994 & 23 \\
\hline 1995 & 21 \\
\hline 1996 & 20 \\
\hline 1997 & 20 \\
\hline 1998 & 19 \\
\hline 1999 & 16 \\
\hline 2000 & 16 \\
\hline 2001 & 16 \\
\hline 2002 & 16 \\
\hline 2003 & 16 \\
\hline 2004 & 16 \\
\hline 2005 & 16 \\
\hline 2006 & 16 \\
\hline & 16 \\
\hline
\end{tabular}

Source: The Nigerian Capital market data bank (2006)

TABLE 2: Activities of Capital Market in Nigeria

\begin{tabular}{|c|c|c|c|c|}
\hline Year & $\begin{array}{c}\text { Market Capitalisation } \\
\text { (NBillion) }\end{array}$ & $\begin{array}{c}\text { No of Listed } \\
\text { Companies }\end{array}$ & $\begin{array}{c}\begin{array}{c}\text { Volume of Shares } \\
\text { (Billion) }\end{array} \\
\end{array}$ & $\begin{array}{l}\text { All Share } \\
\text { Index }\end{array}$ \\
\hline 1988 & 10.0 & 102 & NA & 233.6 \\
\hline 1989 & 12.8 & 111 & NA & 325.3 \\
\hline 1990 & 16.3 & 131 & NA & 513.8 \\
\hline 1991 & 23.1 & 142 & NA & 783.0 \\
\hline 1992 & 31.2 & 153 & NA & $1,107.6$ \\
\hline 1993 & 47.5 & 174 & NA & $1,548.8$ \\
\hline 1994 & 66.3 & 177 & 0.473 & $2,205.0$ \\
\hline 1995 & 180.4 & 181 & 0.524 & $5,092.2$ \\
\hline 1996 & 285.8 & 183 & 0.882 & $6,992.1$ \\
\hline 1997 & 281.9 & 182 & 1.3 & $6,440.5$ \\
\hline 1998 & 262.6 & 186 & 2.1 & 5672.7 \\
\hline 1999 & 300.0 & 196 & 3.95 & $5,266.4$ \\
\hline 2000 & 472.3 & 195 & 5.0 & $8,111.0$ \\
\hline 2001 & 662.5 & 194 & 6.0 & $10,963.1$ \\
\hline 2002 & 764.9 & 195 & 6.6 & $12,137.7$ \\
\hline 2003 & $1,359.3$ & 200 & 13.3 & $20,128.9$ \\
\hline 2004 & $2,112.5$ & 207 & 19.21 & $23,884.5$ \\
\hline 2005 & $2,900.1$ & 214 & 26.7 & $24,085.8$ \\
\hline 2006 & $5,120,000$ & NA & NA & $33,189.3$ \\
\hline 2007 & $13,294,059$ & NA & NA & $57,990.2$ \\
\hline 2008 & $9,562,970$ & NA & NA & $31,450.78$ \\
\hline 2009 & NA & NA & NA & $20,827.10$ \\
\hline 2010 & $10,330.0$ & 217 & $93,340.0$ & $24,770.52$ \\
\hline 2011 & $10,280.0$ & 198 & $89,580.0$ & $20,730.63$ \\
\hline
\end{tabular}


Capital Market and the Development of the Small And Medium-Scale Enterprises in Nigeria.

Sources: 1. Nigeria Stock Exchange Factbook, SEC, 2001;

2. Nigerian Stock Exchange Annual Reports and Accounts, 2005;

3. Central Bank Statistical Bulletin 2007;

4. http://www.databank.sec.gov.ng/allsharepercent.htm 20/1/09;

5. Nigerian Stock Exchange, 2011 Annual Report \& Accounts; P. 7, 2011;

6. SEC, NSE, CBN (various issues), in Donwa, P., and J. Odia; An Empirical Analysis of the Impact of the Nigerian Capital

Market on Her Socio-economic Development; Kamla-Raj: J Soc Sci, 24(2): 135-142, 2010

NA $=$ Not Available

TABLE 3: Transactions at the Nigerian Stock Exchange

\begin{tabular}{|c|c|c|c|c|c|c|c|c|c|c|}
\hline \multirow[b]{2}{*}{ Year } & \multicolumn{3}{|c|}{ Number of Deals } & \multirow[b]{2}{*}{ Total } & \multirow{2}{*}{$\begin{array}{r}\text { \% Growth } \\
\text { of Total }\end{array}$} & \multicolumn{3}{|c|}{ Value (N Million) } & \multirow[t]{2}{*}{ Total } & \multirow{2}{*}{$\begin{array}{r}\% \text { Growth } \\
\text { of Tota }\end{array}$} \\
\hline & Government & Industrial & Equities & & & Government & Industrial & Equities & & \\
\hline 1970 & 303 & 331 & & 634 & - & 16.4 & 0.2 & & 16.6 & - \\
\hline 1971 & 204 & 748 & & 952 & 50.2 & 32.7 & 3.5 & & 36.2 & 118.1 \\
\hline 1972 & 258 & 640 & & 898 & -5.7 & 26.2 & 1 & & 27.2 & -24.9 \\
\hline 1973 & 285 & 537 & & 822 & -8.5 & 91.9 & 0.5 & & 92.4 & 239.7 \\
\hline 1974 & 256 & 2807 & & 3063 & 272.6 & 49.4 & 1.3 & & 50.7 & -45.1 \\
\hline 1975 & 203 & 501 & & 704 & -77.0 & 62.8 & 0.9 & & 63.7 & 25.6 \\
\hline 1976 & 321 & 696 & & 1017 & 44.5 & 111.3 & 0.6 & & 111.9 & 75.7 \\
\hline 1977 & 337 & 1314 & & 1651 & 62.3 & 178.8 & 1.2 & & 180 & 60.9 \\
\hline 1978 & 243 & 2230 & & 2473 & 49.8 & 187.2 & 2.5 & & 189.7 & 5.4 \\
\hline 1979 & 124 & 3099 & & 3223 & 30.3 & 249.7 & 4.7 & & 254.4 & 34.1 \\
\hline 1980 & 220 & 6918 & & 7138 & 121.5 & 380.8 & 7.9 & & 388.7 & 52.8 \\
\hline 1981 & 118 & 10081 & & 10199 & 42.9 & 298.7 & 6.1 & & 304.8 & -21.6 \\
\hline 1982 & 184 & 9830 & & 10014 & -1.8 & 207 & 8 & & 215 & -29.5 \\
\hline 1983 & 292 & 11633 & & 11925 & 19.1 & 384.8 & 13.1 & & 397.9 & 85.1 \\
\hline 1984 & 194 & 17250 & & 17444 & 46.3 & 240.9 & 15.6 & & 256.5 & -35.5 \\
\hline 1985 & 340 & 23231 & & 23571 & 35.1 & 295.3 & 21.3 & & 316.6 & 23.4 \\
\hline 1986 & 270 & 27448 & & 27718 & 17.6 & 477.6 & 20.3 & & 497.9 & 57.3 \\
\hline 1987 & 294 & 42 & 20189 & 20525 & -26.0 & 340 & 42.4 & & 382.4 & -23.2 \\
\hline 1988 & 100 & 0 & 21460 & 21560 & 5.0 & 215.8 & 9.7 & 624.8 & 850.3 & 122.4 \\
\hline 1989 & 171 & 0 & 33273 & 33444 & 55.1 & 582.4 & 0 & 27.9 & 610.3 & -28.2 \\
\hline 1990 & 118 & 49 & 39103 & 39270 & 17.4 & 124.3 & 34.2 & 66.9 & 225.4 & -63.1 \\
\hline 1991 & 45 & 9 & 41716 & 41770 & 6.4 & 92.7 & 6 & 143.4 & 242.1 & 7.4 \\
\hline 1992 & 71 & 14 & 48944 & 49029 & 17.4 & 85 & 6.7 & 400 & 491.7 & 103.1 \\
\hline 1993 & 39 & 28 & 40331 & 40398 & -17.6 & 84.7 & 263.5 & 456.2 & 804.4 & 63.6 \\
\hline 1994 & 16 & 48 & 42010 & 42074 & 4.1 & 15.2 & 177.1 & 793.6 & 985.9 & 22.6 \\
\hline 1995 & 0 & 15 & 49549 & 49564 & 17.8 & 0 & 50.8 & 1788 & 1838.8 & 86.5 \\
\hline 1996 & 11 & 15 & 49489 & 49515 & -0.1 & 12 & 50.8 & 6916.8 & 6979.6 & 279.6 \\
\hline 1997 & 6 & 5 & 78078 & 78089 & 57.7 & 72.6 & 35.3 & 10222.6 & 10330.5 & 48.0 \\
\hline 1998 & 1 & 3 & 84931 & 84935 & 8.8 & 15.6 & 0.2 & 13555.3 & 13571.1 & 31.4 \\
\hline 1999 & 4 & 0 & 123505 & 123509 & 45.4 & 0.8 & 0 & 14071.2 & 14072 & 3.7 \\
\hline 2000 & 8 & 0 & 256515 & 256523 & 107.7 & 8.1 & 0 & 28145 & 28153.1 & 100.1 \\
\hline 2001 & 14 & 0 & 426149 & 426163 & 66.1 & 35.6 & 0 & 57648.2 & 57683.8 & 104.9 \\
\hline 2002 & 3 & 0 & 451847 & 451850 & 6.0 & 2.3 & 0.3 & 59404.1 & 59406.7 & 3.0 \\
\hline 2003 & 1 & 19 & 651697 & 651717 & 44.2 & 3 & 6517.1 & 113882.5 & 120402.6 & 102.7 \\
\hline 2004 & 3 & 13 & 973510 & 973526 & 49.4 & 317.5 & 1730 & 223772.5 & 225820 & 87.6 \\
\hline 2005 & 4 & 19 & 1021943 & 1021967 & 5.0 & 7319.9 & 932.8 & 254683.1 & 262935.8 & 16.4 \\
\hline 2006 & 5 & 1 & 1367948 & 1367954 & 33.9 & 1593 & 72.0 & 468588.4 & 470253.4 & 78.8 \\
\hline 2007 & 0 & 37 & 2614983 & 2615020 & 91.2 & 0 & 1136.5 & 1074883.9 & 1076020.4 & 128.8 \\
\hline
\end{tabular}


Capital Market and the Development of the Small And Medium-Scale Enterprises in Nigeria.

\begin{tabular}{|r|r|r|r|r|r|r|r|r|r|r|}
\hline 2008 & 0 & 138 & 3535493 & 3535631 & 35.2 & 10 & 3528.9 & 1675613.8 & 1679143.7 & 56.1 \\
\hline 2009 & 0 & 15 & 1739349 & 1739365 & -50.8 & 0 & 412.8 & 685304.4 & 685717.3 & -59.2 \\
\hline 2010 & 5 & 0 & 1925471 & 1925478 & 10.7 & 141 & 0.1 & 799896.8 & 799911.0 & 16.7 \\
\hline
\end{tabular}

Sources: $\quad 1$. CBN Statistical Bulletin, 2007

2. Nigerian Stock Exchange Annual Reports and Accounts, 2005

3. Authors' Computations

4. CBN Statistical Bulletin, 2010

References

[1] T. Lemo, “The Role of Financial Institutions in the Growth and Development of the Real Sector"; Being A Paper Presented at the $9^{\text {th }}$ Senior Treasurers' Retreat, Organised by Money Market Association of Nigeria. October 11-13,2002

[2] A.Toktarova, "No 2 Capital Market Opportunities for Financing Small and Medium Size Business"; Project Management Agency (PROMA) Website (2004)

[3] J.C. Anyanwu, O. Oyefusi, A. Oaikhenam and F.A. Dimowo, "The Nigerian Capital Market"; in the Structure of the Nigerian Economy 1960-1997 (Joanee Educational Publishers Ltd, Onitsha, Nigeria, 1997), Chapter 13, pp 212-228.

[4] Ayodele, S.A.; and G.O. Falokun, "Nigeria's Financial and Monetary Systems: The Capital Market" in the Nigerian EconomyStructure and Pattern of Development(Jodad Publishers, Ibadan, 2003), 26-153

[5] UNITAR, Lecture Materials on "Capital Market Development and Regulation"; An Online Course of UNITAR, February - May United States. Institute for Development Strategies, Bloomington.2004

[6] A. S. Hornby; "Development", "Growth"; Oxford Advanced Learner's Dictionary; New Special Price, 6 ${ }^{\text {th }}$ Edition . 2000)

[7] Central Bank of Nigeria (CBN),Annual Report and Statement of Accounts, 1997

[8] N. Hamid, "Role of Capital Markets in Investment Banking Development"; A Speech Presented at ADB; ADB Website. (2004)

[9] D.O.Odife, Implementing the New Partnership for African Development (NEPAS) by Promoting the Development of the SME Sector in the Context of Capital Markets in Africa in Promoting Growth in African Capital Market, UNITAR Document, No. 18. (2002)

[10] S.C. Myers, Capital structure puzzle, Journal of Finance 39, 572-592

[11] E.J. stiglitz and A. Weiss; Credit Rationing in markets with imperfect information. American Economic Review 71, 393-410, 1981

[12] J.E. Bolton; Report of the committee of nquiry of small firms. Bolton report Cmnd 4811, London Hmso 1971

[13] M.R. LeCornu, R.G. McMahon, D.M. Forsaith, \&A.M. Stanger;, 'The Small Enterprise Financial Objective Function: An Exploratory Study', Journal of Small Business Management, 34 (3), 1-14. 1996

[14] B. Ciarán mac an and B. Lucey, Capital Structure and the Financing of SMEs: Empirical Evidence from an Irish Survey. A Paper Presented at the Centre for Economic and Business Research, Copenhagen. (2006)

[15] M.J. Peel, \& N.Wilson, Working Capital and Financial Management Practices in the Small Firm Sector. International Small Business Journal, Vol. 14, No. 2, 52-68. 1996

[16] E.K. Laitinen, Financial Processes in Newly Founded Firms. International Small Firm Journal, 10: 47-55. 1992

[17] S. Holmes, K. Dunston, \& D.Dwyer, The Cost of Debt for Small firms: Evidence form Australia. Journal of Small Business Management, 32: 27-35. 1994

[18] C.Gopinath, Bank strategies toward firms in decline. Journal of Business Venturing: International Entrepreneurship, New Business Development \& Technology, 10(1), 75-92. (1995)

[19] M.O.Olusoji, "Small and Medium Scale Enterprises of the Nigerian Experience"; The Nigerian Journal of Economic History, No.2. 1999

[20] D.B. Audretsch, The Economic Role of Small Medium Sized Enterprises: The united State, world Bank Workshop on SMEs, 2000

[21] Weller, J. "Policy Recommendations on Job Creation: Promoting SME Development", Presented at the Seminar "Job Creation in the Western Hemisphere: Reviewing Best Practices and Setting a New Policy Agenda"2004

[22] Luetkenhorst, W. "Economic Development, the Role of SMEs and the Rationale for Donor Support: Some Reflections on Recent Trends and Best Practices", Paper Presented at the SME Group Meeting, Hanoi. November.2004

[23] Kimki, A. Intergenerational Succession in Small Family Businesses: Borrowing Constraints and Optimal Timing of Succession. Small Business Economics, 9: 309-318. 1997

[24] ILO, Micro and Small Enterprise Development and Poverty Alleviation in Thailand, Final Report and Recommendations, June (2000),.

[25] Nigeria Business Infocom, "The Lagos (Nigerian) Stock Exchange”, www.nigeriabusinessinfo.com/nse/htm, 2004

[26] Oyejide, A.T. (1993), "Financial Liberalisation Under Structural Adjustment and its Implications for Financing Small-Scale and Microenterprises in Nigeria"; IT Publications; pp204-13, 1993

[27] Nigerian Institute of Social and Economic Research (NISER) also in Oyejide (1993), 1987

[28] Rudjito , "Financing Challenges of SME's from the Policy Perspective"; A Paper presented at the 2 nd Annual Conference of PECC Finance Forum. Issues and Challenges for Regional Cooperation in the Asian. Pacific Thailand, July 8-9.2003

[29] Cohn, S. R., "The Development of Micro-Capital Securities Markets in Sub-Saharan Africa: New Approaches to Fostering Enterprise Growth in Promoting Growth in African Capital Markets"; UNITAR Document, No.18. 2003;

[30] The Nigerian Capital Market Data Bank, Interim Report of the Study on the status of Second Tier Securities (SSM) Companies in Nigerian Capital market. . http://www.databank.sec.gov.ng/, 2006

[31] Security and Exchange Commission, Security and Exchange Commission Factbook, 2001

[32] Security and Exchange Commission, Annual Report and Accounts, 2005

[33] Central Bank of Nigeria (CBN),Statistical Bulletin, 2007

[34] Wikipedia, the Free Encyclopedia; The Securities and Exchange Commission (Nigeria); http://en.wikipedia.org/wiki/Securities_and_Exchange_Commission_\%28Nigeria\%29; last modified on 18 May, 2012 at 13:55, 2012

[35] http://www.databank.sec.gov.ng/allsharepercent.htm 20/1/09

[36] Nigerian Stock Exchange; 2011 Annual Report \& Accounts; P. 7, 2011

[37] Donwa, P., and J. Odia; An Empirical Analysis of the Impact of the Nigerian Capital Market on Her Socio-economic Development; Kamla-Raj: J Soc Sci, 24(2): 135-142, 2010

[38] CBN Statistical Bulletin; Table 3: Transactions at the Nigerian Stock Exchange; Financial Statistics; Section A; P. 72, 2010 